\title{
DOCTOR-PATIENT POWER RELATION: A SYSTEMIC FUNCTIONAL ANALYSIS OF A DOCTOR-PATIENT CONSULTATION
}

\author{
Nguyen Thanh Nga* \\ Vietnam Military Medical University, 160 Phung Hung, Phuc La, Ha Dong, Hanoi, Vietnam
}

Received 09 March 2017

Revised 29 April 2017; Accepted 16 May 2017

\begin{abstract}
This paper attempts to explore the power relation between a doctor and a patient through the language they use at a consultation. The consultation is taken from YouTube. The doctor and the patient are women of different ages. The doctor is much younger than the patient. The paper uses systemic functional linguistics as the main theoretical framework, following the top-down approach to analysis; particularly from the analysis of the consultation in terms of field, tenor and mode down to the analysis of the consultation in terms of transitivity, mood and modality. The results of the analysis have revealed that behind the language the doctor and the patient used in their interaction exists social relation in which the doctor has the power over the patient.
\end{abstract}

Keywords: doctor-patient consultation/interaction, systemic functional linguistics, power

\section{Introduction}

For many years, there have been a number of research papers conducted to investigate the language use at doctor-patient consultations. Notably, these studies, mostly based on the Critical Discourse Analysis's (CDA) theoretical lens (Fairclough 2001), have focused on the way doctors use their language to communicate with patients and on how doctors' communicative behavior can influence their clients' satisfaction, compliance and health (Ong et al 1995, Frankel 1990, Ruusuvori 2000, Heath 1992, Robinson \& Heritage 2006, Ainsworth 1992). In Vietnam, besides some sociolinguistic and psychologist studies conducted by Long (2010), Chi et al (2012), Hung (2014), Dung et al (2010), Ha (2000), Hoa (2013) and Phuc (2000) that have shown doctors' behavior and patients' expectation, there has

* Tel.: 84-982204246

Email: nganguyen102005@yahoo.com no linguistic literature that investigates the power English speaking doctors utilize to communicate with their clients. Therefore, this paper will mainly use systemic functional linguistics (SFL) to explore some grammatical characteristics of the doctor's and patient's discourse and will then base on the findings to reveal the doctor's power over the patient through the patient-centered style of consultation. Besides, this paper will also base on CDA theory framework as a supplementary framework to analyze the power found in doctor-patient interaction.

The study is organized around four main parts. Part One is the Introduction. Part Two is concerned with the establishment of the theoretical framework for the study. In this part, this paper will revisit some basic concepts of SFL relevant to the study and set up the theoretical framework for the study. Part Three presents methodological processes such as procedures of data collection as well as data analysis. This part explains the 
process of collecting and analyzing the data from a consultation between a doctor and a patient recorded from YouTube. Part Four includes the findings and discussion that indicate the doctor's power over the patient. Part Five summarizes the main lexicogrammatical features found in the interaction and provides some general conclusions about the language the doctor uses to exercise her power over the patient.

\section{Theoretical framework}

\subsection{Systemic Functional Linguistics}

Halliday has shown that when exploring the meaning of language, SFL 'language as social semiotic'. The language interpreted based on SFL approach is developed respectively in four different strata: context, semantics, lexico-grammar and phonology (Halliday 1994, Halliday 1978, Halliday 1985, Hasan 1993, Hasan 1995, Hasan 1996). Here, SFL claims that the relation between these strata is that of realisation. The lower stratum realizes its next higher one. As phonology is not the concern of this paper, in what follows I will present briefly the three strata: context, semantics and lexico-grammar to establish the framework for analysis.

At the stratum context, SFL postulates that language has three contextual categories: field, mode and tenor (Halliday \& Hasan 1989, Hasan, 1999). Field, 'the nature of the social activity', refers to what is going on through language, to activities and processes that are happening at the time of speech. Tenor, 'the nature of social relations', refers to who is taking part in the dialogue, particularly to the nature of participants such as the relationship between a speaker and a listener and the potential for interacting. Mode, 'the nature of contact', refers to the role of language itself in a given context of situation (Halliday 1978, Halliday \& Hasan 1989, Halliday et al 1964, Gregory \& Carroll 1978). In general, categories of context in SFL - field, mode and tenor, classified as register - are used to study communicative behavior within which all of social interactions occur (Halliday M.A.K 1994, Halliday et al 1964).

At the stratum of semantics, SFL considers this level as a 'source of meaning' (Van 2012, Matthiessen 1995). In the description of language level from the view of the semantic stratum, Halliday categorizes semantics into three metafunctions such as ideational metafunction (including experiential metafunction and logical metafunction), interpersonal metafunction, and textual metafunction. In particular, experiential metafunction views grammar of a clause as representation and is realized by the systems of transitivity. Meanwhile, interpersonal metafunction considers grammar of a clause as exchange and is realized by the systems of mood and modality. Textual metafunction, realized by the system of theme, expresses the grammar of clause as message.

At the stratum of lexico-grammar, Halliday and other SFL authors rank this stratum into a resource for wording meaning and represents language under a set of texts (Halliday 1994, Van 2012, Matthiessen 1995). Lexicogrammar stratum helps us to understand how language is implied through its tool of wording system such as lexis (vocabulary) as well as grammar. In the description of language at the stratum of lexicogrammar, Halliday has indicated that corresponding with the three context-construing strands of meanings ideational, interpersonal and textual, the lexicogrammar stratum is simultaneously realized as wording through the systems of Transitivity, Mood and Theme. At 
this stratum, the language is represented in the forms of wording based on the grammar of the clause in order to reflex our experience (Transitivity), interaction (Mood) and discourse organization (Theme). Particularly, Halliday has stated that the clause has received a special status in SFL because it lies at the intersection of three dimensions: stratification, rank and metafunction (Halliday 1979). The relation of the clause in relation to the overall linguistic system can be represented as follows.

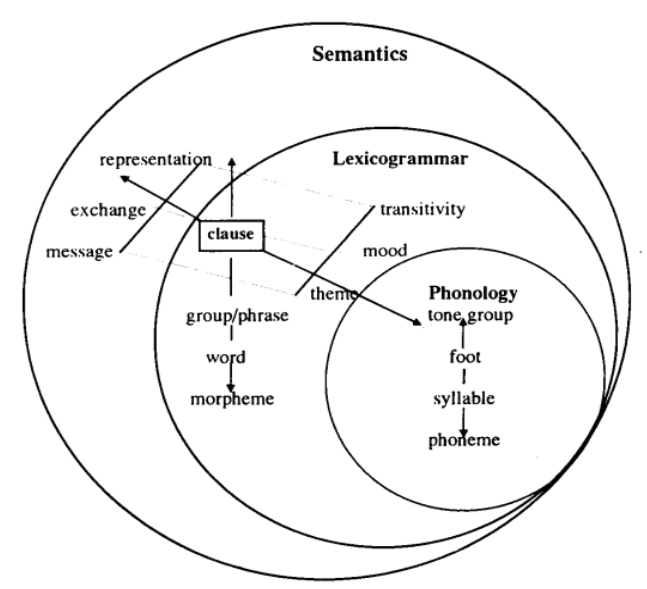

Figure 1. The location of the clause in the overall linguistic system

(Source: Hoang Van Van, 2012)

Convention: $\begin{aligned} & =\text { stratification, } \\ & =\text { metafunction }\end{aligned}$

Van (2012) explains the clause can serve to express the three largely independent sets of semantic choice (representation, exchange and message). By doing this, structures under Transitivity, Mood and Theme are also specifically reflexed. In particular, in terms of rank, the clause holds the highest position when being put into grammatical analysis. Below the clause, there will be a list of constituents, which makes up a clause such as classes of group. Above the clause, there will be a consideration of clause complexes to see how clauses are related to each other to expand or to project meanings.

Due to the limited space of a scientific article, this paper will follow the top-down approach to conduct only the analysis from field, tenor and mode down to the clause transitivity, mood and modality.

\section{Scope of data collection, data collection procedures, and aspects of data analysis}

\subsection{Scope of data collection}

The data, collected from YouTube ${ }^{(1)}$, is an eight-minute video clip of doctor-patient interaction at a consultation. The interaction includes 266 clauses and 55 clause complexes. There are two reasons for selecting this data. First, a live record of a doctor-patient interaction at a consultation can provide both pictures and sound which serve much better than a written text in seeing how interactants create the discourse and what language patterns occur in the context. Secondly, this resource is convenient to access and receives comments on quality from a large number of viewers. The video clip of doctor-patient interaction for this study has been received a great number of good comments and feedback from the viewers.

\subsection{Data collection procedures}

In collecting the data for the study, first, this clip has been chosen from a number of uploaded doctor-patient interaction as it has a Moderate length and includes enough three parts of consultation: Opening, Consulting and Ending. The data was then transcribed into text

\footnotetext{
1 https://www.youtube.com/watch?v=WvNRe0Bh8Q8, uploaded by Jason Bannett on 14th November 2011
} 
based on the system of transcription designed by Eggins and Slade (1997). However, only some transcription symbols such as punctuation, non-transcribe or uncertain segment of talk, filters were taken to serve for the investigation of the study, some others were ignored (e.g. tone, volume, overlapping, etc.). Next, the coding of grammatical symbols was based on Van (2006)'s coding system. Finally, all the data was computerized for the frequency use of grammatical features by both the doctor and the patient. ${ }^{(2)}$

\subsection{Aspects of data analysis}

In order to find out grammatical features of the consultation, the study follows the top-down scale. In general, grammatical features that enable to find the doctor's power over the patient during the consultation are the results of both quantitative and qualitative analyses as follows:

1. An analysis of field, tenor and mode that leads to the general understanding of the nature of the context, social relation and the language used throughout the interaction.

2. An analysis of clause complexes and clause simplexes used by the doctor and the patient to provide background information for the analyses that follow and the evidence of how power is projected;

3. An analysis for the wordings (lexicogrammar) through system of Mood and Modality that leads to the consumption of doctor's power. In particular, the investigation is mainly on the doctor's preferable use of mood choice (declarative, interrogative, and imperative); of modality options (types, values, orientation, and manifestation).

\footnotetext{
2 Due to limited space, an appendix of data analysis cannot be provided. For more details, however, readers, are invited to contact the author by phone at 0982204246 or by email at nganguyen1010025@yahoo.com
}

\section{Findings and discussion}

\subsection{The analysis of Field, Tenor and Mode}

The Field in this discourse is a medical consultation occurring at an institutional setting. This sample of consultation is uploaded to YouTube for educational purposes. In particular, the conversational setting is about a doctor who is providing her patient with a consultation of 'weight control'. The conversation is between a female doctor and a female patient at the doctor's consultation room. Both of them are native speakers of English. The doctor is much younger than the patient. It is clear from the interactions that the doctor and the patient have had some meetings before because at this meeting the patient reports the result of her weight regulation after the previous consultation. Usually, the natural setting of consultation is described with doctor-centeredness where the doctor's power is strongly emphasized because of their professionalism, knowledge, and skills. The Field in this case has been changed because the power is generated from the doctor's persuasiveness, intimacy and understanding. Thus, the shift in the doctor's discourse can be illustrated in the example below. (Pt for Patient and Dr. for Doctor)

(1) Pt: I'm not reading this because I have got a small mount wait. It is just that ... Dr: You are not going to read this, but this,but this is ... this is ... really ... really guilt to those people who have about 10 to ... 30, 40 pounds that you can lose it in any ... a short period of time. And, you will be surprised how much better you gonna feel.

As example (1) indicates, instead of using power to dominate the patient's rejection, the doctor calmly persuades the patient to follow the steps of consultation.

The Field is maintained under the topic of 'weight control' despite the fact that the doctor sometimes shifts the topic to get the 
patient's approval. For example, the doctor changes the topic of 'weight gain' to her kids' daily life. The aim is to get the patient's belief by depending on other practical evidence rather than the doctor's subjective commitment.

(2) Dr: I allow my kids just like "any guys eat something?" and they say: "Ok something like cheese..." (.) [Laughing].

In other cases, the doctor also shifts her discourse when she wants to implement a practical check-up on the patient's body. Here, the doctor makes the patient forget her hand checking that might cause the patient physical pain by friendly talking about one of her colleagues the patient knows.

(3) Dr: I have pressured a bit. I thought Ms.

\section{(.) is wonderful.}

Pt: Umm. She's wonderful.

Rather, in each case of shifting the topic for discussion, the doctor usually prepares her discourse to avoid the patient being misled during the consultation. For example, in order to start her physical hand checking, the doctor says:

(4) Dr: I can listen to your heart while you are lying.

The tenor in this case is a social relation between a doctor (professional) and a patient (a laywoman) at a patient-centered consultation. Here, the Tenor characterizes differently from the traditional ones which consider doctors as decision makers because of their higher social status, greater scientific knowledge. Conversely, in this case, the gap of doctor-patient relation is narrowed as the doctor holds her authority in a subtle manner by tactically offering the patient an equal role during the interaction.

Firstly, the equal role can be realized when the doctor flexibly plays both role of information seeker and provider. In other words, the agentive roles, alternated dynamically between the doctor and the patient, enable the patient to take turns over the doctor.
(5) Dr: This is a couple of mean that makes people used to eat. And then we don't have to know the silly the problem is. And this is why we will try to get back to. So... it looks like...you are... so... 150 pounds, (.) index with 25 and produce lab next visit at the plan, ok? and ... what's your goal?

Secondly, the equal role can be realized when the doctor expresses her politeness during the interaction with the patient. Particularly, the doctor is interested in using positive declarative clauses with modal operators in many cases of imperative (more details and examples can be seen in Section 4.3).

The mode of this consultation is a dialogue between a doctor and a patient through a spoken channel, face-to-face interaction. Both verbal and non-verbal linguistic patterns have constitutively contributed to the signs of relatively equal interactivity between the doctor and the patient. In terms of non-verbal communication such as the doctor's facial expressions, the office layout, and the uniform the doctor wears, have contributed markedly to the signal of patient-centeredness (Als 1997, Greatbatch et al 1995). In a research study that aims to compare the effect of doctors' verbal and non-verbal communication on patient enablement, Teresa et al (2012) concluded that doctors' non-verbal interaction, e.g. nodding, leaning forward, laughing can bring about more elements of interpersonal exchanges. Although the doctor in this current study was busy with explaining the diagnosis and analysis, she was observed to be warm and intimate with her smiling and nodding during that time while listening to the patient's narratives. Devlin (2015, p. 56) and many designers of medical workspaces have argued that there lies a closed relationship between 'seating' and 'social interaction' at doctors' office. These authors emphasizes on the role of designing doctors' office suite that enable to improve the healthcare 
quality (Charmerl 2003, Cooper \& Marni 1999, McGill 2010). It can be observed that there was no physical barrier as the doctor and the patient shared a close physical distance in their seating. During the time of the consultation, the two were found to be talking socially because the distance was so close that the doctor only needed to move her chair a little when she wanted to implement her manual examination. Besides, while the patient wears patient clothes, the doctor wears her casual clothes inside and a white blouse outside. Normally, uniforms are used to identify the difference among entities. Here, uniforms can characterize the distinction between a professional and a nonprofessional, between the doctor and the patient. However, the doctor's mixing fashion of casual and formal style partially reduces the institutional atmosphere and gives the patient an environment with pleasure. Thus, this realization supports to what Miles et al (2013) have found in a survey research on patient's preference on doctor's attire. The authors suggested that patients prefer doctors wearing white coats with scrubs such as jeans, shirts because this image can significantly improve patients' confidence and comfort during the consultation.

In terms of verbal communication, the Mode of the consultation which proves the doctor's subtle power can be seen through the use of thematisation in doctor-patient interaction. Particularly, the doctor has employed a number of conjunctives (80 instances) and continuants (20 instances) as well as the use of unmarked in
Topical Theme indicates that the doctor tends to use cohesive, coherent, but less interruptive consultation strategies. The doctor always provides her patient with a chance to become involved in the consultation with a number of continuants such as fine, great, $\mathrm{OK}, \mathrm{Mmm}$, $\mathrm{mhm}, \mathrm{hm}, \mathrm{umm}$, yeah, and oh. Here, the doctor has shown her subtle power by encouraging the patient to expose ideas and opinions about the patient's physical state.

In general, field, tenor and mode can describe the general context of the consultation. As can be seen, the context of situation in this study is an illustration of a subtle power being generated from new concept of medical consultation - patientcenteredness. Under this type of consultation, doctor's choice of language, moving towards informality and solidarity politeness, can gain effectively the communicative purposes. Here, both the doctor and the patient become engaged in the consultation 'through which the particular structure and organization of the medical interview is jointly constructed'. (Hyden \& Mishler 1999, p. 176)

\subsection{The analysis for interclauses of Transitivity}

The first analysis is on clause simplexes and clause simplexes. The clause simplex boundary is indicated by $\|$ and clause complex boundary is indicated by $\| \mid$. Table 1 shows the use of clause simplexes and clause complexes by the doctor and the patient.

Table 1. Clause simplex and clause complex used by the doctor and the patient

\begin{tabular}{|c|c|c|c|c|c|c|c|}
\hline \multirow{2}{*}{$\begin{array}{c}\text { Type/ } \\
\text { percentage }\end{array}$} & \multicolumn{3}{|c|}{ Doctor } & & \multicolumn{3}{|c|}{ Patient } \\
\cline { 2 - 3 } \cline { 6 - 7 } & Simplex & $\begin{array}{c}\text { Clause } \\
\text { complex* }\end{array}$ & $\begin{array}{c}\text { Total N. of } \\
\text { clause }\end{array}$ & & $\begin{array}{c}\text { Clause } \\
\text { simplex }\end{array}$ & $\begin{array}{c}\text { Clause } \\
\text { complex* }\end{array}$ & $\begin{array}{c}\text { Total N. of } \\
\text { clause }\end{array}$ \\
\hline TOTAL & 28 & 162 & 190 & & 49 & 27 & 76 \\
\hline$\%$ & 14.73 & 85.26 & 100 & & 64.47 & 35.52 & 100 \\
\hline
\end{tabular}

* The total number of clauses in clause complexes 
Table 1 shows that the total number of clause simplexes and clause complexes used by the doctor during the consultation is 190 , of which the number of clause simplexes is 28 (accounting for $14.73 \%$ ) and that of clause complexes is 162 (accounting for $85.26 \%$ ). By contrast, the total clause simplexes and clause complexes used by the patient during the consultation is 76 , of which the number of clause simplexes is 49 (accounting for $64.47 \%$ ) and that of clause complexes is 27 (accounting for $35.52 \%$ ).

The comparison of clause simplex and clause complex used during the encounter can illustrate the participants' preferred strategies of interaction during the consultancy. As can be seen, while the doctor dominates the frequency use of clause complex $(85.26 \%)$ to extend her explanation and persuasion, the patient seems to have preference of using clause simplex to provide the doctor with clearly single responses. The frequency of clause simplex uttered by the patient is $64.47 \%$, representing a triple percentage as compared to $14.73 \%$ of the frequency of clause simplex used by the doctor.

The second analysis is on the clause complexes - the relation between clause complex of Taxis and logico-semantic. The former is concerned with interdependency relations. The two options within the system of Taxis are those of Parataxis or Hypotaxis.
In a clause complex, if one clause is dependent on or dominates another, the relation between them is a hypotactic one; if they are of equal status, the relation is a paratactic one. Meanwhile, the latter is concerned with a wide range of possible Logico-Semantic relationships between clauses. The two options within the system of Logico-Semantic are those of Projection and Expansion. Projection is traditionally called reported speech. A paratactic relation holds when one clause quotes another, and a hypotactic relation when clause reports another. Expansion is concerned with three types Elaboration, Extension and Enhancement. (For more details, see Halliday 1994, Matthiessen 1995, Vân 2012).

Basing on the above theoretical background, my focus is on counting for the number of paratactic and hypotactic relations appeared in clause complex to decide whether the semantic relations of the text are expansion or projection. In this section, the reason why there is no comparison on the frequency of use of taxis and logico-semantic relations between doctor and patient is simply that the doctor has a remarkably dominant use of clause complexes (Table 1), resulting in the dominant use of every criterion belongs to taxis and logico-semantic. Therefore, the following table only shows the doctor's use of taxis and logico-semantic in clause complex.

Table 2. The doctor's frequent use of Taxis and Logico-Semantic in clause complexes

\begin{tabular}{|c|c|c|c|c|c|c|c|}
\hline \multirow{2}{*}{$\begin{array}{c}\text { Taxis and } \\
\text { Logico- } \\
\text { Semantic }\end{array}$} & \multicolumn{2}{|c|}{ Taxis } & \multicolumn{5}{c|}{ Logico-Semantic } \\
\cline { 2 - 8 } & Para & Hypo & \multicolumn{3}{c|}{ Expansion* } & \multicolumn{2}{c|}{ projection } \\
\hline Type & & & Elaboration & Extension & Enhancement & Idea & Locution \\
\hline $\begin{array}{c}\mathbf{N}^{0} \text { of } \\
\text { frequency }\end{array}$ & 127 & 152 & 32 & 93 & 43 & 1 & 0 \\
\hline Total & \multicolumn{2}{|c|}{279} & & & 169 & 0.6 & 0 \\
\hline$\%$ & 45.5 & 54.5 & 18.9 & 55 & 25.5 & 0.6 \\
\hline
\end{tabular}


As can be seen from the table, the doctor strategically uses both hypo-taxis and parataxis clause complexes. The aim is to provide the patient with a cohesion narrative of consultation. Here, the content of the advice the doctor provides the patient tends to link cohesively from sentences to sentences.

In particular, Table 2 shows a slight dominance of hypotactic relation than paratactic relation (accounting for $54.5 \%$ compared with $45.5 \%$ ). Here, both hypotactic and paratactic relations are used with different aims. When the doctor emphasizes the steps of treatment procedure, she uses paratactic sequence to focus on the orders of the physical performance.

\section{(6) III You can also look at this number,}

\section{1}

|| so you will watch your body,

$$
x 1.2
$$

|| so you also watch your body fat,

$$
x 1.3
$$

|| so that the decrease (.) may not better much. |||

$$
x 1.4
$$

Meanwhile, hypotactic relation is mostly used when the doctor aims to expand her opinions or explanation, in other words, to supply the patient much more information on the discussion issue.

(7) || For the first two days you may feel a little WEIRD

$$
1 \alpha
$$

|| as you start to get into (.),

$$
x 1 \beta
$$

I| then you will be better within 3 or 4 days. |||

\section{$x 2$}

In particular, the semantic relations are mainly of extension (accounting for 55\%). Thus, among the expansion of logicosemantics, the extension effectively helps the doctor provide her client with further explanation. For example, among 162 clause complexes spoken by the doctor, around 40 clause complexes include the conjunction and that indicates the most frequent signal of extension.

(8) I|| I can go backfor week,

\section{1}

|l and do my high protein, low carb

$$
+1.2
$$

1 and really get back to that

$$
+1.3+2 \alpha
$$

|| and

you need to keep an eye on your

weight, you know, forever

$+28$

Only one clause complex, exposed by the doctor, quoted relation which characterizing the dialogic portion. Thus, the projection of logico-semantic has been almost unused because this consultation is face-to-face interaction, the doctor preferred using a direct rather than indirect speech.

\subsection{The analysis for mood and modality}

Throughout this section, the investigation is mainly on the doctor's use of mood and modality options. The analysis for mood and modality is based on Halliday (1994) and Halliday (2012).

\subsubsection{The analysis for mood}

As suggested by Halliday (1994, p. 95), the mood analysis mainly depends on major and minor clauses that are divided into positive and negative form and embody the basic mood choice (declarative, interrogative and imperative). A major positive/negative clause is a clause which has a mood component and indicates polarity (e.g. The medication is/ isn't in the same family) even though that pood component is probably sometimes omitted (e.g. Yes/No, I have/haven't). A minor clause, on the other hand, is a clause which has no 
mood and functions as a constituents (e.g. OK, Well, Right, Uhm, Mmm). Details of mood analysis are presented in Table 3. doctor's high use of major declarative clauses presumably due to the responsibility for providing the patient with more detailed information during the consultation. This

Table 3. Number and frequency of use of mood by the participants $(n=205 ; 100 \%)$

\begin{tabular}{|c|c|c|c|c|c|c|c|c|c|}
\hline \multicolumn{5}{|c|}{ Doctor } & \multicolumn{5}{|c|}{ Patient } \\
\hline & \multicolumn{2}{|c|}{ Major } & \multicolumn{2}{|c|}{ Minor } & & \multicolumn{2}{|c|}{ Major } & \multicolumn{2}{|c|}{ Minor } \\
\hline & pos. & neg. & pos. & neg. & & pos. & neg. & pos. & neg. \\
\hline Decl. & $\begin{array}{c}113 \\
(55.1 \%)\end{array}$ & $\begin{array}{c}11 \\
(5.4 \%)\end{array}$ & $\begin{array}{c}13 \\
(6.3 \%)\end{array}$ & 0 & Decl. & $\begin{array}{c}28 \\
(13.6 \%)\end{array}$ & $\begin{array}{c}1 \\
(0.48 \%)\end{array}$ & $\begin{array}{c}22 \\
(10.7 \%)\end{array}$ & $\begin{array}{c}1 \\
(0.48 \%)\end{array}$ \\
\hline Interro. & $\begin{array}{c}8 \\
(3.9 \%)\end{array}$ & 0 & 0 & 0 & Interro & $\begin{array}{c}2 \\
(0.9 \%)\end{array}$ & 0 & 0 & 0 \\
\hline Imper. & $\begin{array}{c}6 \\
(2.9 \%)\end{array}$ & 0 & 0 & 0 & Impe. & 0 & 0 & 0 & 0 \\
\hline $\begin{array}{c}\text { Total } \\
151 \\
(73.7 \%)\end{array}$ & $\begin{array}{c}127 \\
(61.9 \%)\end{array}$ & $\begin{array}{c}11 \\
(5.4 \%)\end{array}$ & $\begin{array}{c}13 \\
(6.3 \%)\end{array}$ & $\begin{array}{c}0 \\
(0 \%)\end{array}$ & $\begin{array}{c}\text { Total } \\
54 \\
(26.3 \%)\end{array}$ & $\begin{array}{c}30 \\
(14.6 \%)\end{array}$ & $\begin{array}{c}1 \\
(0.48 \%)\end{array}$ & $\begin{array}{c}22 \\
(10.7 \%)\end{array}$ & $\begin{array}{c}1 \\
(0.48 \%)\end{array}$ \\
\hline
\end{tabular}

* Decl: Declarative; Interro: Interrogative; Imper: Imperative; pos: positive; neg: negative

In general, both major and minor positive clauses record a dramatically high frequency use by the participants. Besides, interrogative mood registers a slightly higher use than imperative mood, however, both of them are seen at a low frequency choice, particularly, no option can be seen with major negative and minor mood.

In particular, while the doctor is interested in using major positive declarative mood, the patient prefers using minor positive mood. Thus, the doctor deploys $55 \%$ of the major positive declaratives, accounting for nearly fivefold higher than that of the patient's. Meanwhile, the patient shows a nearly double use of minor declarative mood accounting for $10.7 \%$, compared to that of the doctor's which is only $6.3 \%$. Only $3.9 \%$ of interrogative mood, a quadruple percentage comparing with that of the patient's, is used by the doctor. Besides, there is only $2.9 \%$ of imperative mood used by the doctor, meanwhile, no instance of this type of mood used by the patient.

In terms of declarative mood, the coincides with what is found with the doctor's preferred use of complex clauses. Here, the doctor uses declarative mood to extend her explanation to persuade the patient to follow the advice. Example (9) serves to illustrate the point.

(9) II The medicine is in the same family. III And if you do well with the divided dozes, || the new will start (.). ||| We can always move to the other pills $\|$ and see how you feel |lor you're just hungry all the time. III

This suggests a logic structure of interaction that the doctor uses a large number of major declarative clauses to persuade the patient with convincing information and explanation, meanwhile, the patient shows her agreement with the doctor by minor responses. Interestingly, the minor positive clauses, such as ah, huh, well, ok, great; right, fine, good, uhm, alright, mmm, mhm, hm, umm, yeah, and $o h$, used more often by the patient during the interaction. Thus, they act as expected 
responses that construe the interactivity of the consultation. Also, the doctor uses the minor clauses because she wants the patient to become engaged in the consultation. Here, the minor declaratives can be considered as signals of the doctor's attention to the patient's narrative. The doctor wants the patient to continue by occasional giving minor responses to minimize the tendency of interrupting and taking over the patient. Conversely, the doctor uses the go-ahead signals such as oh, good, yeah... to keep the patient talking of her own experiences, feelings and expectation as well.

In terms of interrogative mood, the doctor projects questions with different aims of interaction. The doctor uses wh-questions when she wants to seek information from the patient's personal information.

(10) I| how tall are you? ||

(11) ||| May I ask || how long were you in that weight, 125? ||

\section{(12) I| what about the mood? I|}

Thus, the doctor may rely on the medical data to have the answers; however, asking the patient to review her own physical health or state can help the doctor implement a share-knowledge consultation strategy. For these questions, the doctor knows that the patient can answer them well because the patient surely has a much broader view of her own health in general.

Moreover, the doctor also projects some polar interrogatives with the expectation of opening answers.

\section{(13) || Any other questions? ||}

(14) $\mid$ Have you $\sim$ ever taken any medication for weigh control before in the past $\|$.

Normally, when a yes/no question is projected, the speaker wants the listener to specify with agreement or disagreement. In other words, a polar question may lead the listener to a limited range of responses such as acceptance or rejection. Exchanges of interpersonal meanings made probably limited to yes and no responses. However, basing on Halliday's (1995, p. 69) system of speech functions and responses that covers the explanation of 'expected response' and 'discretionary alternative', this study finds that at the time the doctor initiates a polar question, the patient keeps talking about her own physical and emotional state. As a result, the doctor projects polar questions to expect the patient to keep acting the role as an information provider, not a passive listener. Thus, with polar questions, the doctor offers the patient a floor to express more information about the patient's problems. As a result, the doctor can employ further about the patient's desire and expectation.

$$
\begin{aligned}
& \text { Dr: || Any other questions? || } \\
& \text { Pt: || No, I'm just concerned about the } \\
& \text { medication. ||| I have never used this, } \\
& \text { || so I have found some troubles |||. }
\end{aligned}
$$

Besides, the doctor also projects some questions for confirmation starting with declarative clauses.

(16) |||You are all gonna take great parties, || gonna have Christmas, || gonna have these things, I| but you need to be prepared, ok? |||

With a rising intonation of the minor declarative clause $o k$, the doctor seeks for the patient's agreement and confirmation. Supposedly, if the doctor keeps conducting a prolonged talk without getting the patient involved into the conversation, the patient will fail to follow the doctor's narrative. The confirmative question ok enables the doctor to offer the patient opportunity to take turn to express whether the patient agrees with the doctor's advice. Thus, the doctor's interrogative strategy illustrates the trend of patient-centeredness. Here, the addressee the patient - actively engages the conversation by taking turns, moves, and floor through the doctor's initiation and regulation.

In terms of imperative mood, the doctor aims at non-open negotiation in some cases that require the patient seriously to follow. However although the doctor expresses her 
authoritarian to control the consultation by some forcing imperatives, the patient actually obeyed the doctor's command with pleasure. Here, the doctor has tactically conducted a polite and delicate way of consultation by inaugurating modality before using imperatives. Thus, this type of consultation provides the doctor with the opportunity to do her job well without putting any pressure on the patient.

(17) II Make sure your mood is fine with this ||and your pressure is stable. ||

However, in other cases of instructive imperatives such as 'Deep breath, breath out, again and again' the doctor sends a message to inform the patient a probability of physical hurt before she intends to do her hand checking on the patient's heart.

(18) ||| I can listen to your heart || while you are lying. || $\mid$

(19) || I have pressured a bit. ||

Apparently, under this context of medical consultation, the doctor holds a higher position as she acts as a role of medical representative, being responsible for the patient's health. Therefore, the doctor certainly possesses the power over the patient. However, in this case, the doctor expresses her dominant power in another way. The imperatives the doctor uses functions as a mild instruction only, not as a command or an order.

\subsubsection{The analysis for modality}

The term modality is understood differently by different grammarians. As this study employs systemic functional linguistics as the theoretical framework, it follows Halliday's conceptualization of modality which is comprised of four parameters: (1) Types (consisting of assessment of propositions in relation to probability or usuality and of proposals in relation to obligation or inclination); (2) values (consisting of assessment grade in terms of high, medium, and low); (3) orientation (consisting of responsibility for assessment in relation to objective and subjective) and (4) Manifestation (consisting of individual variation in relation to explicit and implicit). The results of modality that come from the modal categories of types and values are presented in Table 4.

Table 4. Number and frequency use of modality types and values by the participants

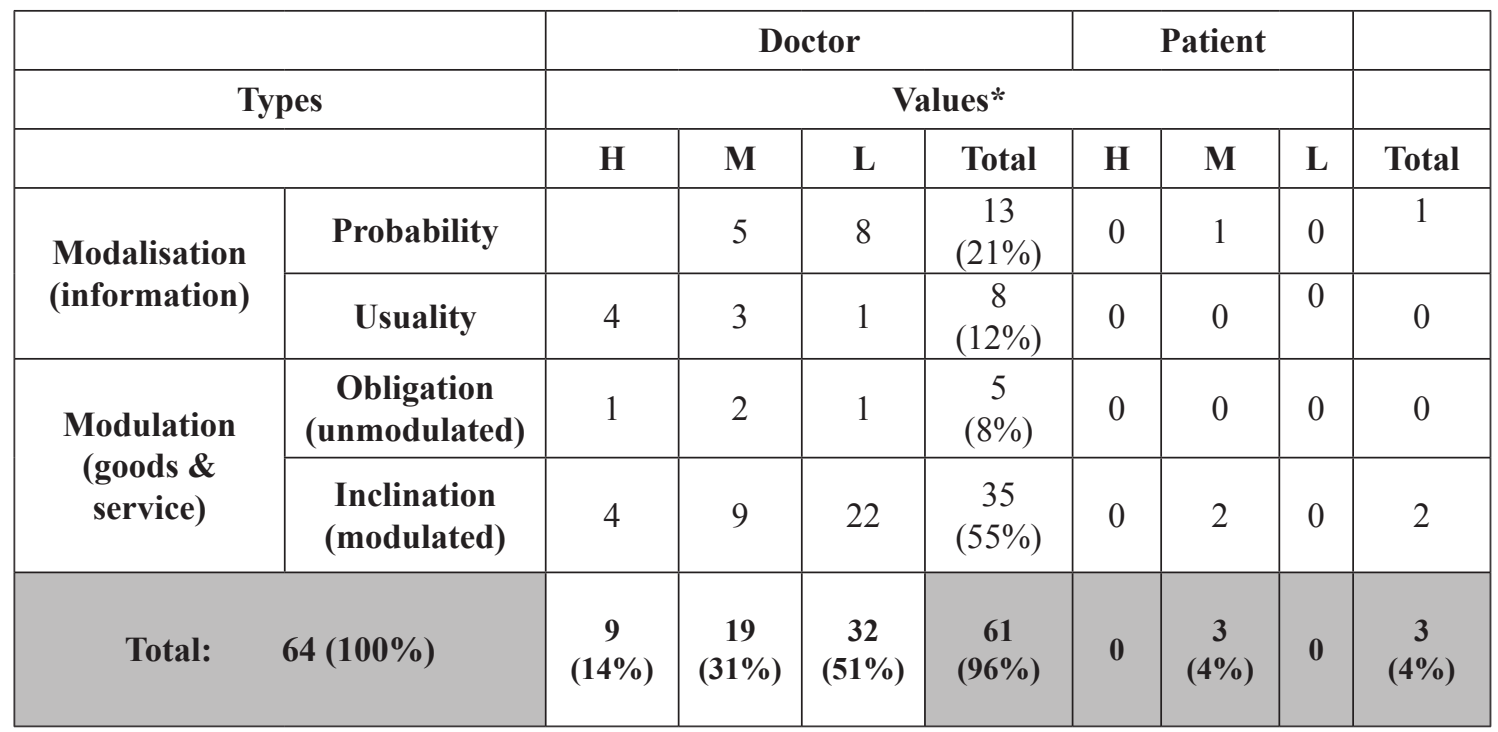

* H: High; M: Medium; L: Low 
Table 4 shows that the total number of modals used by the doctor is 61 , accounting for $96 \%$ while the total number of modals used by the patient is only $4 \%$. The doctor's dominant use of modals can be seen in both modality types: modalisation and modulation. Notably, modality of probability will/ may/might and inclination need/will/would/should/can have been preferably used, comparing with the two other types of modality such as Usuality always/usually/sometimes and obligation have to. Particularly, comparing with the second highest modality of probability, the inclination has registered a double higher frequent use, accounting for $55 \%$. Besides, the doctor's modal option is gathered mainly at medium and low values, respectively accounting for $31 \%$ and $51 \%$. Meanwhile, there is only $14 \%$ of modal operators, such as always/have to/ need/needn't at high value.

The higher percentage of modulation, compared with that of modalisation, indicates that the doctor prefers using modal operators to exchange 'goods and services' rather than providing 'information'. In other words, as the doctor tends toward a consultation of patient-centeredness, she pays more attention to conducting a reciprocal speech than singly supplying information. In fact, for the clauses exchanged in terms of 'goods and service', the modal operators function as an effective tool that helps the patient feel secure about the doctor's explanation and persuasion. Without these modalities, the doctor's narrative tends to be direct, unmodulated, and apparently difficult to get the patient's agreement and satisfaction. Conversely, in this case, the patient understands that the doctor has attempted to choose the most suitable diagnosis for the patient to follow at ease.

(20) I|| I think ||that should be the better choice for you. |||

However, it cannot be denied that, clauses of exchanging information also plays an important role in providing patient medical knowledge in the Field of her disease.

(21) $\|$ For the first two days, you may feel a little weird. ||

(22) II You will be better within 3 or 4 days. || You will get used to that. ||

Although the doctor has warned the patient beforehand of unexpected effect, with the use of modalities may and will, the doctor is able to help the patient to overcome the mental fear of the treatment side effect. Thus, the modal verb may helps the doctor appease the patient that the negative impact does not always happen and if it does, it will not last for a long process. The modal verb will, on the other hand, serves as a strong confirmation that assures the patient of the doctor's best choice of treatment.

Furthermore, the modal of Inclination is used more frequently than that of the obligation. While the former functions as an instrument of polite consultation practice, the latter, on the other hand, is a useful tool that helps the doctor to express her power 'behind' discourse. Here, the doctor gives priority to the patient's satisfaction and desire, not to the treatment workload. For the clauses of Inclination, the modalities majorly gather at low level of certainty like need, will, should, can and may function as persuasion or request when the doctor wants the patient to follow the treatment procedure in a polite consultation practice. Thus, by using the modalities of Inclination at medium and low level of values, the doctor is able to switch her voice and let the patient be calmly persuaded to follow the doctor's instruction.

(23) I| You should do well, \| you should motivate it $\|$ and right now investigating yourself. \|

(24) II you need to keep an eye on your weight. ||

Besides, clauses with modal operators of obligation, on the other hand, enable the 
doctor to express her 'power' over their patients with warm and friendly controls through the flow of the interaction. In this case, obligation or commands which include modal operators at three level of values such as not have to, shouldn't helps the doctor both express her authority to do her job well and avoids a form of imperative and direct consultation. and explicit variants to the subjective and objective orientation of modality. Based on what Halliday has systemized, in Table 5, this paper shows the examples of doctor's use of modality types that come from the modal categories of Orientation and Manifestation.

Table 5. An overview of modality type and orientation combined the doctor used

\begin{tabular}{|c|c|c|c|c|}
\hline \multirow[t]{2}{*}{ Types } & \multicolumn{4}{|c|}{ Orientation combined } \\
\hline & Subjective: explicit & Subjective: implicit & Objective: explicit & Objective: implicit \\
\hline $\begin{array}{l}\text { Modalisation: } \\
\text { Probability }\end{array}$ & $\begin{array}{c}\text { This is something I } \\
\text { think very durable } \\
\text { programme. }\end{array}$ & $\begin{array}{l}\text { For the first two } \\
\text { days you may feel } \\
\text { a little WEIRD }\end{array}$ & $\begin{array}{l}\text { This is really ... } \\
\text { really guilt to those } \\
\text { people who have } \\
\text { about } 10 \text { to ... 30, } 40 \\
\text { pounds that you can } \\
\text { lose it in any ... a } \\
\text { short period of time. }\end{array}$ & $\begin{array}{c}\text { It's gonna be } \\
\text { after that a } \\
\text { slow weight } \\
\text { loss, typically } \\
\text { (sluggish) weight } \\
\text { loss. }\end{array}$ \\
\hline $\begin{array}{l}\text { Modalisation: } \\
\text { Usuality }\end{array}$ & & $\begin{array}{l}\text { You will divide, } \\
\text { usually about } 30 \\
\text { minutes before you } \\
\text { eat or take water } \\
\text { with these pills. }\end{array}$ & & $\begin{array}{l}\text { We can always } \\
\text { move to the other } \\
\text { pills }\end{array}$ \\
\hline $\begin{array}{l}\text { Modulation: } \\
\text { Obligation } \\
\text { (unmodulated) }\end{array}$ & $\begin{array}{l}\text { I wish to see how } \\
\text { you react to using it }\end{array}$ & $\begin{array}{c}\text { You shouldn't try } \\
\text { to leave liver cut in } \\
\text { meats. }\end{array}$ & & $\begin{array}{c}\text { So you also } \\
\text { watch your body } \\
\text { fat. }\end{array}$ \\
\hline $\begin{array}{l}\text { Modulation: } \\
\text { Inclination } \\
\text { (modulated) }\end{array}$ & $\begin{array}{c}\text { I mean ...it is not } \\
\text { the depression }\end{array}$ & $\begin{array}{l}\text { You will watch } \\
\text { your body. }\end{array}$ & $\begin{array}{l}\text { This is important to } \\
\text { look at everything, } \\
\text { and also the interest, } \\
\text { you know, that ..also } \\
\text { come off as well. }\end{array}$ & $\begin{array}{l}\text { Mmm... with the } \\
\text { medicine that we } \\
\text { have available, } \\
\text { you easily use two } \\
\text { different types }\end{array}$ \\
\hline
\end{tabular}

II| This is a couple of mean || that makes people used to eat || $\mid$ and then we don't have to know $\|$ the silly the problem is. |||

(26) III You should not to be stuck at number,|| look at the big picture. |||

Halliday (1994, pp. 357-358) claims that modality orientation is the basic distinction that is used to determine how each modality meaning gets expressed. Meanwhile, the modality manifestation indicates implicit
Table 5 illustrates some modality choices in the doctor's talk that exemplify subjectivity and objectivity of explicit/implicit orientation. In terms of explicit assessment, subjective-explicit, realized by the 'Senser' and the mental verbs, explicitly represents the speaker $I$ - referring to the doctor, and indicates the doctor's own point of view with verbal markers think, wish, understand. This type of assessment allows the doctor to highlight her prominent opinions, assertion 
as well as tentativeness, and under this case, to pass her responsibility and decision to the patient. Explicitly objective type, realized by intensive attribute relational clause such as $I t$ is ...; This is..., functions as an effective means of conducting persuasive purposes. Thus, this type of judgment depends on providing practical evidence to call for the patient's acceptance.

Meanwhile, implicit assessment does not represent the speaker-the doctor's judgments. Rather, it enacts the doctor's opinion and agreement degree on what is projected by the patient. Here, while subjective implicit is realized by finite modal operator may, will, should, objective-implicit is marked with comment adjuncts especially, typically, well, also, always, sometimes.

Table 6 presents the distribution of subjectivity and objectivity of explicit/implicit orientation by the doctor during the interaction.
- you and the finite modal operators such as can, may, should, would, might, will, need. In fact, of $66 \%$ frequent choices of implicit subjectivity, two third of them is exposed with modal clauses such as you can/may/should/ would/might/will/need. The doctor uses much you, attaching with modal operators to express her expectation and opinions about what the activities should be done by the patient.

(27) || you can drop that night-time doze. ||

The doctor's preferable use of implicit subjectivity indicates an adaptation of a patient-centered strategy at consultation. Here, the doctor aims to pay mostly attention to the patient, not to her own judgment or commitment. In other words, when expressing propositions, the doctor considers the patient as a central role and gives the patient a prior position in her narrative. Thus, this style of medical consultation actually helps the doctor

Table 6. Modality Orientation and Manifestation used by the doctor

\begin{tabular}{|c|c|c|}
\hline Orientation & Frequency & Percentage \\
\hline Subjective: explicit & 9 & $15 \%$ \\
\hline Subjective: implicit & 40 & $66 \%$ \\
\hline Objective: explicit & 2 & $3 \%$ \\
\hline Objective: implicit & 10 & $16 \%$ \\
\hline Total & $\mathbf{6 1}$ & $\mathbf{1 0 0} \%$ \\
\hline
\end{tabular}

Of the 61 modal clauses, most of them are skewed towards subjectivity, totally accounting for around 80\%. Conversely, explicitly objective assessment is classified as the lowest level of percentage, accounting for only $3 \%$ in total. Meanwhile, explicit subjectivity and implicit objectivity are equally ranked at around $15 \%$.

In particularly, the doctor is favoured by using implicitly subjective assessment with the subjective operator referring to the patient improve the patient's autonomy. Here, the patient understands she is the one that needs actively enact a subjective role during the treatment procedure.

Explicitly subjective assessment, on the other hand, realized by the subjective operator $I$ - referring to the doctor herself and by the verbal markers think, wish, understand, mean, is used in only some cases when the doctor wants to highlight her own opinions and commitment. In this study, with the combination of the mental verbs think/wish/ 
understand/mean, the doctor can project her inner belief with a tender impact on the patient. However, this assessment type, accounting for $13 \%$, ranks at the second lowest position and allocates mainly in the region of Probability and Inclination.

(28) ||| So I think, || you might be better with that one.||

(29) ||| So I think || you should do well. || You should motivate it. \|

While explicitly subjective assessment of probability can show the doctor's judgment on an uncertain fact, that of Inclination, illustrates the doctor's management of building a shared and intimate consultation. Table 5 indicates that explicitly subjective assessment used by the doctor with different aims. For example, in one case that the doctor is unsure whether the patient can respond well to the diagnosis, or side effects might or might not come, the doctor projects a mental clause $I$ think in the region of probability. By doing this, the doctor strategically provides the patient with a positive comment that is able to relieve the patient's nervousness and anxiety. Here, the doctor consults the patient not only with concrete knowledge but also with shared experience from her deeply inside consciousness. Besides, mental clauses in the region of Inclination help the doctor consult the patient in a way of sharing responsibility. In this case, the doctor may project I wish to expect or to call for the patient's cooperation to make the treatment improved; I understand to express her intimacy and sympathy when the patient tells about her fear and sorrow of the treatment side effect; I mean to extend her explanation to make a simple discourse that helps the patient understand at ease; and I think to highlight her comment as a subtle adjustment to ask the patient to follow her advice with pleasure. In this way, the doctor can both puts no pressure on the patient and shows her inner opinions that have no impact on the patient's physical world. In other words, the doctor can share her sole responsibility to the patient, enhance the patient's autonomy and independence, and build up a cooperative atmosphere with the patient.

Furthermore, the lower percentage use of objectivity indicates that the doctor strategically prefers expressing autonomy through her introspective assumptions rather than from the outer reflective opinions. As the discourse of face-to-face consultation is unplanned and happens naturally, the doctor prefers persuading the patient by her own practical knowledge, experience and inner belief rather than indirectly by someone else's point of views. It was only in two cases that the doctor aims to make her point of view appear to be neutral. The doctor takes example of other people's feelings and experience to make her suggestions or consultation sound more acceptable and persuasive.

(30) $\|$ This is $\sim \|$ this is ... really ... really guilt to those people $\|$ who have about 10 to ... 30, 40 pounds. ||

(31) || This is important to look at everything, and also the interest. III You know, \|that ...also comes off as well. \||

This type of assessment effectively functions as a means of encouraging acceptance. The doctor may quickly get the patient agreement since she depends on the obvious evidence rather than on her insistence or her personal reasoning. However, it may restrict the negotiation as it disguises the fact that the doctor has provided the patient with strong evidence supporting by other viewpoints, therefore, the patient can easily show her approval without any response.

In contrast to the little favour of explicitly objective type, the doctor shows a relatively preferred option of implicitly objective assessment. In this study, implicit objectivity, is realized by comment adjuncts such as 
especially, typically, well, also, always, sometimes. Halliday and Matthiessen (2004, p. 129) claim that this type of assessment reflexes the speaker's attitude either to the proposition as a whole or to particularly speech function. In this study, implicitly objective assessments with comment adjuncts, occur in declarative clauses, help the doctor clearly express general opinions and plans for the treatment with a less directive and imperative voice. They also enable the doctor to weaken the intensity of the statements, moreover, tactically dominate the patient in a subtle manner. Examples of implicit objectivity in table 5 can illustrate remarkable functions of this assessment type. The doctor may flexibly include her judgment on the probability of the slow progressive result.

(32) II It's gonna be after that a slow weight loss, typically (sluggish) weight loss. ॥

guide the patient thoroughly the frequency of taking medicine;

(33) ||| So sometimes the other pill is just a day pill || that lasts all day long. |||

ask the patient to take more care of her weight;

(34) || So you also watch your body fat. ||

or to persuade the client to follow the advice.

(35) II you prepare well with weight loss, especially in the first week. \|

Implicitly objective comments are located more in the two main types: Usuality and inclination. It can be explained that the implicit objectivity gathers round the usuality and inclination types because the doctor pays more attention on thoroughly instructing the patient the time and the manner of conducting the treatment.

(36) $\|$ We can always move to the other pills. $\|$

(37) || Mmm... with the medicine that we have available, I| you easily use two different types $\|$.
Despite the different distribution of subjectivity and objectivity of explicit/implicit orientation by the doctor when interacting with her patient, this paper proves that the doctor has conducted an intimate, polite, and persuasive consultation. The doctor has shown her subtle power through reciprocal interaction with the patient, leading to the increase of the patient's autonomy and independence. By doing this, the doctor shortens the distance with the patient and builds an interactive relationship with the patient during the consultation.

\section{Conclusion}

This study has investigated the grammatical characteristics of context, clause complexes and clause simplexes, and Mood and Modality to reveal the power lying behind the doctor's discourse. In general, the following grammatical features contribute a well-founded evidence for the power that lies behind the doctor's words at the consultation.

- Evidence from the context of situation:

Field, mode and tenor

The field of the consultation is a movement toward the alternative forms of consultation practice - patient-centeredness. The evidence, which proves the change of the field relating to the doctor's subtle power, is generated from persuasiveness and intimacy, not from professionalism, knowledge, or skill. The tenor of the consultation is an equally relative status between a doctor (professional) and a patient (a laywoman) at a consultation. The tenor is not an issue of one-sided talk between physicians and their patients as it is normally described (Adam, 2004). The tenor found in this case is relatively symmetrical because the agentive roles, information seeker and giver, are alternated dynamically between the doctor and the patient. The mode of the consultation is a relatively equal dialogue. For non-lexical choice, the evidence can be found from the 
doctor's facial expression, layout office, and uniform. For the verbal choice, the study finds a number of cohesive and coherent, but less interruptive consultation strategies through the doctor's large use of conjunctives, continuants and unmarked in Topical Theme.

- Evidence from the use of clause complexes and clause simplexes

There is a greater use of clause complexes by the doctor and of clause simplexes by the patient. Particularly, there is a higher use of clause complexes by the doctor in hypotactic relation compared with that of in paratactic relation; an almost no use of ideal projection or quoted relation.

- Evidence from the use of mood and modality

In terms of mood, there is a dramatically higher frequent use of major and minor declarative mood by the doctor compared with that by the patient; A considerable use of interrogative mood by the doctor with different interactive aims of seeking information or negotiating for approvals; A seldom use of unmarked positive imperatives and no use of unmarked negative imperatives.

In terms of modality, there is a totally dominant use of modality by the doctor at medium and low values, being mainly distributed into modality of probability (will, may, might) and of inclination (need, will, would, should, can); a noticeable use of modal clauses skewing towards subjectivity, particularly, implicitly subjective assessment - you, referring to the patient; a relatively preferable use of implicitly objective and explicitly subjective assessment; a relatively little use of explicit objectivity.

From the results of the study, this paper provides some conclusions as followings:

In general, the study confirms that the doctor has expressed her power over the patient during the interaction. However, being different from the traditional consultation that is empowered by a doctor's higher position and knowledge, this study reveals the doctor's subtle power characterizing by politeness, solidarity and intimacy. In particular, in terms of context, the change of field, tenor and mode towards politeness originally comes from the movement in English that entailed a shift in the language of doctors. Thus, 'language, like everything else is joining in the general flux' (Aitchison 2000, p. 3). That means that there has never been a moment where a 'true standstill in language' exits. As a result, the language of doctors that underlies the system of general language is also moving towards increasing informality and solidarity. In terms of clause complexes and simplexes, the prominent use of clause complexes, particularly, hypotactic relation rather than paratactic relation indicates a new model of consultation that appeals the doctor to extend sentences by using mainly simple words and phrases instead of complex medical jargons; to provide intimate persuasion instead of direct imperative instruction. In terms of mood and modality, the doctor's greater use of major, minor declarative and interrogative mood, however, a seldom use of unmarked positive imperatives, proves the doctor's tactical and polite strategies in explaining and encouraging the patient at the consultation. Besides, a large number of modalities skewing towards implicit subjectivity imply the doctor's attempt to focus on improving the patient's democratic arguments and autonomy. Thus, mood and modal instruments, have contributed a great help to the doctor to weaken her authority power and encourage the patient's confidence and self-control. The doctor, in this case, has followed the trend of patient-centeredness as she expresses her power over the patients in a polite way. In other words, the doctor's power in this study is the power behind discourse in reciprocal consultation that aims to take the patients' concerns and expectations into account.

Thus, the language of doctors has always been expressed very powerfully 
through their discourse. This has now been changed to become much more subtle. In this case, the power in the language of the doctor is minimized to create a friendlier environment, and to increase the patient's autonomy as well.

\section{Acknowledgements}

I wish to sincerely thank my supervisor, Prof. Dr. Hoang Van Van, for his thorough and conscientious supervision. I have benefited greatly from his generosities of providing me with valuable materials, giving me edifying feedback as well as advice with regard to this paper.

\section{References}

\section{English}

Adam, Q (2014). A study of power relations in doctor-patient interactions in selected hospital in Lagos State, Nigeria, Advances in Language and Literary Studies, No 5-2, 177-184.

Ainsworth-Vaughn, N (1992). Topic Transition in Physician-Patient Interviews: Power, Gender, and Discourse Change", Language and Society, No 21, 409-26.

Aitchison, J (2000). Language Change: Progress or Decay?, 3 rd ed. Cambridge: Cambridge University Press.

Als, A. B (1997). 'The desk-top computer as a magic box: patterns of behaviour connected with the desk-top computer: GPs' and patients' perceptions'. Fam Pract. No 14(1), $17-$ 23. Available through $<$ PubMed $>$, Accessed 28/4/2017 15:42.

Charmerl, P. A (2003). Building the Business Case for Patient-centred Care, (In) Suan, B, Frampton, Laura G \& Patric. A. Charmel (Eds.), Putting Patients First: Designing and Practicing Patient-Centred Care. San Francisco: Jossey-Bass, 193-204.

Cooper, M; Clare \& Marni, M (1999). Acute Care General Hospitals: Case studies and Design
Guildelines. (In) Calre C, M and Marni B (Eds) Healing Gardens: Therapeutic Bebefits and Design Recommendations. New York: John Wiley \& Sons, Inc, 212.

Devlin, A. S (2015). Transforming the doctor's office - principles from evidence based design. New York, Routledge.

Eggins, S \& Slade, D (1997). Analyzing Casual Conversation, London, Continuum.

Fairclough, N (2001). Language and Power, $2^{\text {nd }}$ ed, London, Longman,

Frankel, R (1990). Talking in Interviews: A Dispreference for Patient-initiated Questions in Physician-Patient, (In) Pasathas. G, (Ed.), Interactional competence, Washington, University Press of America, 231-262.

Greatbatch, D; Heath, C; Campion, P; Luff, P. (1995). How do desk-top computers affect the doctor-patient interaction? Fam Pract. No 12(1), 32-36. Available through $<$ PubMed $>$, Accessed 28/4/2017 15:46.

Gregory, M \& Carroll, S (1978). Language Varieties and Their Social Contexts, London, Henley and Boston: Routledge \& Kegan Paul.

Halliday, M.A.K (1978). Language as Social Semiotic: The Interpretation of Language and Meaning. London, Edward Arnold.

Halliday, M. A. K, (1979). Modes of Meaning and Modes of Expression: Types of Grammatical Structure and Their Determination of Different Semantic Functions, (In) Allerton. D. J., Carney. E., \& Holdcroft. D (Eds.), Functions and Contexts in Linguistic Analysis: Essays Offered to William Haas, Cambridge: Cambridge Universtiy Press, 57-79.

Halliday, M.A.K (1985). Spoken and written language, Geelong, Vic: Deakin University Press.

Halliday, M.A.K (1994). An Introduction to Functional Grammar, $2^{\text {nd }}$ ed, London, Edward Arnold.

Halliday, M. A. K, (2012). Dẫn luận ngũ pháp chức năng. In lần thứ 2. Hoàng Văn Vân dịch. Hà Nội: Nxb. Đại học Quốc gia Hà Nội.

Halliday, M. A. K \& Matthiessen, C. M. I. M(2004). An Introduction to Functional Grammar, $3^{\text {rd }}$ ed. London, Edward Arnold. 
Halliday, M.A.K \& Hasan, R (1989). Language, context, and text: Aspects of language in a social-semiotic perspective: Language Education, $2^{\text {nd }}$ ed., Oxford, Oxford University Press.

Halliday, M. A. K; McIntosh, A \& Strevens, P (1964). The Linguistic Sciences and Language Teaching, London: Longmans.

Halliday, M. A. K \& Hasan, R (1989). Language, Context and Text, Oxford: Oxford University Press.

Hasan, R (1993). Context for Meaning, (In) Alatis. J. E. (Ed.), Georgetown University Round Table on Languages and Linguistics, 1992: Language, Communication and Social Meaning. Washington D.C.: Georgetown Universtiy Press, 79-103.

Hasan, R (1995). The Conception of Context in Text, (In) Vol. L., Fries, P. H. \& Gregory. M (Eds.), Discourse and Meaning in Society: Systemic Functional Perspectives. Meaning and Choice in Language: Studies for Michael Halliday. Norwood, NJ: Alblex.

Hasan, R (1996). Semantic Networks, (In) Cloran. C., Butt. D. G., \& Wiliams. G (Eds.), Ways of Meaning: Selected Papers of Rugaiya Hasan. London.: Cassell, 104-131.

Hasan, R (1999). Speaking with reference to Context. (In) Ghadessy. M (Ed.), Text and Context in Functional Linguistics, Amsterdam/ Philadelphia, John Benjamins Publishing Company, 219-328.

Heath, C (1992). The Delivery and Reception of Diagnosis in the General-Practice Consultation, (In) Drew. P and Heritage, J. (Eds), Talk at Work: Interaction in Institutional Settings, Cambridge, Cambridge University Press.

Hoàng Văn Vân (2006). Introducing Discourse Analysis, Hà Nội, Nxb Giáo dục.

Hoàng Văn Vân (2012). An Experiential Grammar of the Vietnamese Clause, Hà Nội, Nxb. Giáo dục.

Hyden, L. C \& Mishler, E.G (1999). Language and Medicine. Annual Review of Applied Linguistics, No 19, 174-192.

Matthiessen, C (1995). Lexicogrammatical Cartography: English Systems, Tokyo International language Science Publishers.
McGill, D (2010). 'Devola Funk's Health Care Reminder: 'You fell healthier when you're dressed'. Available through $<$ http://archive.is/ jR2v30 >, Accessed 28/4/2017 15:38.

Miles, L; Adriana, C; Genevieve, H and Richard, E. D. (2013). Patient Preferences for Doctor Attire: The White Coat's Place in the Medical Profession. The Ochsner Journal, V 13, No3 $\underline{31}$

Ong, L. M., J. C. J. M. de Haes, A. M. Hoos \& F. B Lammes (1995). Doctor-patient communication: A review of the literature. Social Science and Medicine, No 40, 903-918.

Robinson, J \& J, Heritage (2006). Physicians' Opening Questions and Patients' Satisfaction, Patient Education and Counseling, No 60, 279-285.

Ruusuvori, J (2000). Control in the Medical Consultation: Practices of Giving and Receiving the Reason for the Visit in Primary Health Care, A Ph.D. Dissertation, University of Tampere.

Teresa, P; Wenjuan, Z; Frances, G; Jan, V. D; Cess, V (2012). Verbal and non-verbal behavior of doctors and patients in primary care consultations - How this relates to patient enablement. Patient Education and Counseling, No. 86, 70-76.

\section{Vietnamese}

Nguyễn Khánh Chi, Đoàn Công Khanh và Bùi Văn Dũng (2012). Đánh giá sự hài lòng của người bệnh về chất lượng dịch vụ khám chữa bệnh tại khoa Khám bệnh, bệnh viện đa khoa Đông Anh, thành phố Hà Nội, năm 2011. Hội nghị khoa học công nghệ tuổi trẻ các trường đại học-cao đẳng y duợc Việt Nam, chuyên ngành điều duỡng, 8-16.

Phan Thị Dung, Trần Nguyễn Ngọc Minh, Nguyễn Thị Thiện và cộng sự (2010). Thực trạng kỹ năng giao tiếp với người bệnh của đội ngũ nhân viên y tế tại bệnh viện Việt Đức. Hội nghị khoa họ điều dương nhi khoa toàn quốc lần thứ VII. Bệnh viện Nhi Trung ương, 148-156.

Nguyễn Thị Thanh Hà (2000). Vấn đề giao tiếp của bác sĩ quân y với nguời bệnh trong quá trình khám và chũa bệnh. Luận án tiến sĩ Quân sự. Học viện chính trị Quân sự. 
Lê Thu Hòa (2013). Nghiên cứu thưc trang dạyhoc môn Đạo đức y học trong đào tạo bác sĩ tại các truòng đại học $Y$ và đánh giá kết quả can thiệp thư nghiệm. Luận án tiến sĩ Y học. Trường Đại học Y Hà Nội.

Đỗ Mạnh Hùng (2014). Nghiên cứu thực trạng nhận thức thực hành Y đức của điều duõng viên tại bệnh viện Nhi Trung Uơng và kết quả một số biện pháp can thiệp. Luận án tiến sĩ Y tế Công cộng. Thái Bình: Trường Đại học $\mathrm{Y}$ Dược Thái Bình.
Chu Văn Long (2010). Thực trạng giao tiếp ứng xử của cán bộ y tế đối với người bệnh và gia đình người bệnh tại bệnh viện Việt Đức. Hội nghị khoa học điều duỡng Nhi khoa toàn quốc lần VI, 134-144.

Nguyễn Sinh Phúc (2000). Co' sở tâm lý hoc của sụ hình thành và phát triển nhân cách nguoời bác sĩ quân $y$. Luận án tiến sĩ Quân sự. Học viện chính trị Quân sự.

\title{
MỐI QUAN HỆ QUYỀN LỰC GIŨ̃A BÁC SĨ VÀ BỆNH NHÂN: PHÂN TÍCH MỘT BUỔI TU'VẤN KHÁM BỆNH GIŨ்A BÁC SĨ VÄ BÊNH NHÂN TỬ CÁCH TIẾP CẬN CHỨC NĂNG HỆ THỐNG
}

\author{
Nguyễn Thanh Nga \\ Học viện Quân y, 160 Phùng Hung, Phuờng Phúc La, Quận Hà Đông, Hà Nội, Việt Nam
}

Tóm tắt: Mục đích của bài viết này là tìm ra mối quan hệ quyền lực giữa bác sĩ và bệnh nhân thông qua kênh ngôn ngữ được sử dụng tại phòng khám tư vấn. Clip buổi tư vấn khám bệnh được tải từ YouTube. Cả bác sĩ và bệnh nhân đều là nữ, bác sĩ ít tuổi hơn nhiều so với bệnh nhân. Bài viết sử dụng khung phân tích Chức năng hệ thống làm cơ sở lý luận chính, tiếp cận theo đường hướng diễn dịch (từ trên xuống). Cụ thể, bài viết bắt đầu phân tích từ ngôn cảnh bao gồm: trường, không khí và phương thức xuống tới cấp độ ngữ pháp - từ vựng theo các bình diện chuyển tác, thức và tình thái. Kết quả cho thấy ẩn sau ngôn ngữ được sử dụng để giao tiếp giữa bác sĩ và bệnh nhân luôn tồn tại mối quan hệ xã hội, trong đó bác sĩ luôn nắm quyền chủ đạo.

Từ khóa: Khám tư vấn/giao tiếp bác sĩ - bệnh nhân, ngôn ngữ học chức năng hệ thống, quyền lực 